\title{
TRAINING OF TRAINER (PELATIHAN UNTUK PELATIH) BAGI KADER PEMBERDAYAAN EKONOMI DESA (KPED)
}

\author{
Tri Nurdyastuti ${ }^{1)}$ \\ Adi Penawan ${ }^{2)}$ \\ Lukman Ahmad Imron Pahlawi ${ }^{3)}$ \\ STIE Adi Unggul Bhirawa \\ lukman.pahlawi@gmail.com
}

\begin{abstract}
Community service is aimed at helping to improve the skills of a trainer and understanding as a facilitator for village economic empowerment cadres (KPED) and management of beneficiary groups of revolving fund funds for community empowerment of UPK-PDB DAPM Kecamatan Kalijambe Sragen regency. The method used in this Community Service activity is in the form of training assistance on ways to become a counseling staff for KPED and management of beneficiary group of Revolving Fund Fund of Community Empowerment Trust Fund (PDB DAPM) in Kalijambe Sub-district, Sragen Regency. From the training result showed that the average understanding of the material before and after the training was done to the Training of Trainers participants, before the average training of understanding on the material from 35 participants was 60,9 , meanwhile after being given the average training of participants understanding 89.4. The value of $t_{\text {hitung }}-15.929$ with sig $0.000<0.05$, it means that the mean of understanding before and after the implementation of Training of Trainer to the participants there is a difference. Thus it can be stated that the delivery of the Training of Trainer material greatly influences the participants' understanding.
\end{abstract}

Keywords: Training of Trainer, Activity Management Unit (UPK)

\begin{abstract}
ABSTRAK
Kegiatan pengabdian kepada masyarakat ini bertujuan membantu meningkatkan keterampilan sebagai seorang pelatih serta pemahaman sebagai seorang fasilitator bagi kader pemberdayaan ekonomi desa (KPED) dan pengurus kelompok penerima manfaar pinjaman dana bergulir dana amanah pemberdayaan masyarakat UPK-PDB DAPM Kecamatan Kalijambe Kabupaten Sragen. Metode yang digunakan dalam kegiatan Pengabdian Kepada Masyarakat ini berbentuk pendampingan pelatihan tentang cara-cara menjadi seorang tenaga pendamping bagi KPED dan pengurus kelompok penerima manfaat Pinjaman Dana Bergulir Dana Amanah Pemberdayaan Masyarakat (PDB DAPM) di Kecamatan Kalijambe Kabupaten Sragen. Dari hasil Pelatihan menunjukkan bahwa rata-rata pemahaman terhadap materi sebelum dan sesudah dilakukan pelatihan pada peserta Training of Trainer, sebelum pelatihan ratarata pemahaman terhadap materi dari 35 orang peserta adalah sebesar $60,9 \%$, sementara setelah diberikan pelatihan rata-rata pemahaman peserta sebesar $89,4 \%$. Nilai $t_{\text {hitung }}$ sebesar -15.929 dengan sig $0.000<0.05$, artinya rata-rata pemahaman sebelum dan sesudah pelaksanaan Training of Trainer terhadap peserta terdapat perbedaan. Dengan demikian dapat dinyatakan bahwa penyampaian materi Training of Trainer sangat mempengaruhi terhadap pemahaman peserta pelatihan.
\end{abstract}

Kata kunci: Training of Trainer, Unit Pengelola Kegiatan (UPK)

\section{PENDAHULUAN}

Keberlangsungan kelembagaan Unit Pengelola Kegiatan Pinjaman Dana Bergulir Dana Amanah Pemberdayaan Masyarakat (UPK-PDB DAPM) lebih tergantung pada komitmen masyarakat dalam upaya kesejahteraan dirinya. Peran tugas UPK juga sebagai pengelola dana bergulir untuk pelayanan pinjaman kepada kelompok-kelompok masyarakat, dituntut untuk mampu menerapkan strategi yang tepat, efektif 
dan efisien dalam kinerjanya sehingga UPK akan bisa menjaga kelestarian dan keberlanjutan dana yang saat ini di kelola.

Unit Pengelola Kegiatan (UPK) adalah lembaga yang dibentuk Musyawarah Antar Desa (MAD) dengan fungsi sebagai pengelola dana bergulir dan memberdayakan masyarakat lokasi kegiatan PNPM Mandiri Perdesaan. (Paryanto, 2015). UPK Kalijambe terbentuk pada tahun 2003. Tumbuh dan berkembangnya Lembaga UPK PNPM-MP tidak terlepas dari kerjasamanya, partisipasi serta kontribusi dari pemerintah, kelembagaan yang terbentuk dari kegiatan PNPM-MP dan masyarakat setempat, serta Pendamping (Fasilitator).

UPK kalijambe hadir dengan semangat yang berbeda dengan lembaga perkreditan yang selama ini beredar di masyarakat. UPK langsung menuju pada kelompok yang selama ini tidak terlayani oleh lembaga keuangan formal (bank). UPK Kalijambe masuk di desa dan langsung bersaing dengan lembaga pelepas uang (rentener atau bank plecit/harian) yaitu rumah tangga miskin.

Dari hal tersebut diatas Sumber Daya Manusia yang berkualitas diharapkan mampu menentukan dan menjamin terlaksananya kegiatan kelompok secara efektif dan efisien. Untuk itu, perlu adanya tenaga khusus yang akan memberikan pendampingan kelompok yang senantiasa bisa memotivasi kepada kelompok dan anggota penerima pinjaman dana dari UPK. Melihat terbatasnya jumlah personil karyawan UPK maka dalam kegiatan pendampingan perlu kerjasama dengan Kader Pemberdayaan Ekonomi Desa (KPED) dan Pengurus kelompok peminjam itu sendiri untuk bisa diberdayakan sebagai tenaga fasilitator pendampingan/Petugas Coaching Clinic dalam melatih, mendampingi serta membantu dalam manajemen pengelolaan dana pinjaman di kelompok.

KPED/Pengurus Kelompok agar mampu menjadi seorang fasilitator dan pendamping bagi kelompok penerima manfaat, maka dibutuhkan bekal pengetahuan, ketrampilan dan cara-cara menjadi seorang tenaga pendamping. Oleh karena itu pada kegiatan ini akan di adakan Training of Trainer bagi KPED dan Pengurus Kelompok.

Training of Trainer (TOT) bertujuan untuk menjadikan seseorang siap menjadi Trainer (Pengajar) baik secara teknis maupun non teknis. Pendekatan yang tepat dalam TOT dilakukan melalui experiencetial learning, dimana peserta training/pelatihan mengalami pengalaman sebagai Trainer secara langsung selama pelatihan, dan mendapatkan feedback dari peserta dan evaluasi dari Fasilitator Trainer.

Training/Pelatihan adalah akuisisi pengetahuan keterampilan dan kompetensi sebagai hasil dari pengajaran keterampilan kejuruan atau praktis dan pengetahuan yang berhubungan dengan kompetensi yang berguna tertentu. Pelatihan memiliki tujuan spesifik untuk meningkatkan kemampuan seseorang, kapasitas, produktivitas dan kinerja.

Tujuan proses Training of Trainer (TOT) adalah untuk memberi pelatih baru pengetahuan latar belakang, keterampilan dan pengalaman praktis untuk memberikan pelatihan dan bantuan teknis bagi Komunitas tersebut kepada masyarakat. (J. David Hawkins and Richard F. Catalano, 2004:1).

Pelaksanaan kegiatan tim Pengabdian Kepada Masyarakat Sekolah Tinggi Ilmu Ekonomi Adi Unggul Bhirawa (STIE-AUB) Surakarta ini akan berusaha membantu meningkatkan keterampilan sebagai seorang pelatih serta pemahaman sebagai seorang fasilitator bagi kader pemberdayaan ekonomi desa (KPED) dan pengurus kelompok penerima manfaar pinjaman dana bergulir dana amanah pemberdayaan masyarakat UPK-PDB DAPM Kecamatan Kalijambe Kabupaten Sragen.

\section{METODE PELAKSANAAN}

Kegiatan Pengabdian Kepada Masyarakat ini berbentuk pelatihan tentang training of trainer (pelatihan untuk pelatih) bagi kader pemberdayaan ekonomi desa (KPED) dan pengurus kelompok penerima manfaar pinjaman dana bergulir dana amanah pemberdayaan masyarakat UPK-PDB DAPM Kecamatan Kalijambe Kabupaten Sragen.

Materi pelatihan ini diberikan dalam teori dan praktek yaitu:

1. Ketrampilan Dasar Melatih

a. Mengenal Diri dan Mengenal Orang Lain

b. Teknik Komunikasi 
c. Teknik Kerjasama

d. Kepemimpinan Dalam Pelatihan Partisipatif

e. Citra Diri Pelatih

2. Konsep Pelatihan Partisipatif

a. Dasar-Dasar POD (Pendidikan Orang Dewasa)

b. Media Pelatihan Partisipatif

c. Metode Pelatihan Partisipatif

d. Prinsip-Prinsip POD (Pendidikan Orang Dewasa)

3. Pengembangan Kurikulum

a. Analisa Kebutuhan Pelatihan

b. Pengembangan Kurikulum

4. Teknik Fasilitasi

a. Teknik Bertanya dalam POD

b. Kiat Sukses Fasilitasi

\section{Indikator Keberhasilan}

Indikator keberhasilan dalam pelaksanaan pendidikan dan pelatihan kegiatan Pengabdian Kepada Masyarakat ini adalah sebagai berikut:

1. Bentuk evaluasi adalah dengan pretest dan posttest

2. Kriteria evaluasi adalah ketetapan dan keberhasilan penerapan teori dan praktek yang diberikan oleh pelaksana Pengabdian Kepada Masyarakat Bentuk evaluasi adalah pengamatan dan wawancara tentang teori dan praktek setelah diadakannya pelatihan.

\section{HASIL DAN PEMBAHASAN}

Peserta pelatihan yang hadir dalam kegiatan pengabdian kepada masyarakat sejumlah 35 orang, adapun tahapan pelaksanaan kegiatan adalah sebagai berikut:

1. Ketua dan anggota tim kegiatan pengabdian pada masyarakat ini membagikan pretest materi Training of Trainer dan dikerjakan oleh peserta.

2. Narasumber melakukan postest materi Training of Trainer dan dikerjakan kembali oleh peserta.

Dari hasil pretest dan posttest yang dilakukan tim pada saat pengabdian dianalisis. Analisis dilakukan dengan menggunakan uji beda untuk mengetahui apakah terdapat perbedaan pemahaman tentang materi yang diberikan sebelum pelatihan dan sesudah pelatihan.

\section{Hasil analisis data pretest dan posttest}

Paired Samples Statistics

\begin{tabular}{|ll|l|r|r|c|}
\hline & & & & Std. Error \\
& & Mean & N & Std. Deviation & Mean \\
\hline Pair & Pretest & 60,8571 & 35 & 7,90437 & 1,33608 \\
1 & Posttes & 89,4286 & 35 & 5,78683 &, 97815 \\
\hline
\end{tabular}


Paired Samples Test

\begin{tabular}{|c|c|c|c|c|c|c|c|c|}
\hline & \multicolumn{5}{|c|}{ Paired Differences } & \multirow[b]{3}{*}{$\mathrm{t}$} & \multirow[b]{3}{*}{ df } & \multirow[b]{3}{*}{ Sig. (2-tailed) } \\
\hline & \multirow[b]{2}{*}{ Mean } & \multirow[b]{2}{*}{ Std. Deviation } & \multirow{2}{*}{$\begin{array}{c}\text { Std. Error } \\
\text { Mean }\end{array}$} & \multicolumn{2}{|c|}{$\begin{array}{c}95 \% \text { Confidence } \\
\text { Interval of the } \\
\text { Difference }\end{array}$} & & & \\
\hline & & & & Lower & Upper & & & \\
\hline Pair 1 Pretest - Posttes & $-28,57143$ & 10,61155 & 1,79368 & $-32,21662$ & $-24,92623$ & $-15,929$ & 34 &, 000 \\
\hline
\end{tabular}

Sumber : data diolah, 2017

Dari hasil diatas menunjukkan bahwa rata-rata pemahaman terhadap materi sebelum dan sesudah dilakukan pelatihan pada peserta. Sebelum pelatihan rata-rata pemahaman terhadap materi dari 35 orang peserta adalah sebesar 60,9 , sementara setelah diberikan pelatihan rata-rata pemahaman peserta sebesar 89,4 .

Nilai t hitung sebesar -15.929 dengan sig $0.000<0.05$, artinya rata-rata pemahaman sebelum dan sesudah pelatihan Training of Trainer terhadap peserta terdapat perbedaan. Dengan demikian dapat dinyatakan bahwa penyampaian materi Training of Trainer sangat mempengaruhi terhadap pemahaman peserta pelatihan.

\section{EVALUASI}

Keberhasilan pelaksanaan program pengabdian masyarakat ini dilihat dari dua indikator yaitu :

1. Respon positif dari peserta yang hadir dari awal hingga kegiatan berkahir

2. Hasil pretes (tes sebelum penyampaian materi) dan posttes (tes setelah penyampaian materi) menunjukkan adanya peningkatan nilai dimana setelah penyampaian materi pemahaman peserta tentang manajemen organisasi lebih baik.

\section{PENUTUP}

\section{Kesimpulan}

Berdasarkan hasil dan pembahasan kegiatan pengabdian kepada masyarakat yang telah diuraikan sebelumnya, dapat disimpulkan bahwa :

1. Pemahaman peserta tentang pentingnya pengetahuan sebagai Trainer semakin tinggi setelah mengikuti pelatihan.

2. Kemampuan peserta pelatihan meningkat dari bagaimana menjadi Fasilitator, Pelatih dan Pendamping bagi kelompok simpan pinjam, serta mampu dan terampil mendesain dan membuat rencana pelatihan bagi Kelompok Penerima Manfaat.

\section{Saran}

Penyelenggaraan program pengabdian kepada masyarakat dengan bentuk penyelenggaraan Training of Trainer sangat diperlukan bagi penerima dana pinjaman dan diharapkan kegiatan seperti dapat dilakukan secara berkesinambungan.

\section{UCAPAN TERIMA KASIH}

Ucapan terima kasih disampaikan kepada UPK PNPM-MPd Kecamatan Kalijambe dan STIE AUB Surakarta yang telah menerbitkan surat tugas sehingga pelaksanaan kegiatan ini dapat berjalan dengan lancar. 


\section{DAFTAR PUSTAKA}

J. David Hawkins, Ph.D., and Richard F. Catalano, Ph.D., 2004, Training of Trainers, The Center for Communities That Care is part of the Social Development Research Group, School of Social Work, University of Washington.

Nur Sayyid S. K., 2008, Modul Panduan Training of Fasilitator. Yogyakarta

Paryanto, 2015, Selamatkan Asset PNPM, UPK Harus Berbadan Hukum, Jurnal Warga, http://www.karanganyarkab.go.id/20150224/selamatkan-asset-pnpm-upk-harus-berbadan-hukum/

Sugeng Paranto, dkk. 1980. Micro Teaching. Jakarta. Departemen Pendidikan dan Kebudayaan. 